\title{
Banks, domestic debt, and crises: The recent Brazilian experience*
}

\author{
Bancos, divida interna e crises: A recente experiência brasileira
}

\author{
AFONSO S. BEVILAQUA** \\ MÁRCIO G. P. GARCIA***
}

\begin{abstract}
RESUMO: Este artigo examina a evolução recente da dívida pública brasileira e a interpreta à luz da literatura sobre crise de confiança. A análise dos desenvolvimentos recentes no mercado brasileiro de dívida pública mostra que a probabilidade de inadimplência não deve ser avaliada apenas usando medidas agregadas simples e resumidas do tamanho e maturidade da dívida pública doméstica, mas também deve considerar outros aspectos estruturais. Nossa análise enfatiza os dois principais pilares do mercado doméstico de dívida pública brasileira: o viés doméstico e o papel do setor bancário na intermediação da dívida. Evidências dos rendimentos de um título indexado "perfeitamente" mostram que o prêmio de rolagem era muito pequeno quando a desvalorização ocorreu e ainda é bastante pequeno em outubro de 1999, indicando que a rolagem da dívida pública não é, até o momento, um grave problema. As perspectivas positivas para o mercado público de dívida doméstica dependerão, no entanto, da manutenção pelo governo brasileiro do atual programa de austeridade fiscal.
\end{abstract}

PALAVRAS-CHAVE: Bancos, Dívida Pública, Crises de Moeda, Economia Brasileira

ABSTRACT: This paper examines the recent evolution of the Brazilian public domestic debt and interprets it in light of the confidence crisis literature. The analysis of the recent developments in the Brazilian public domestic debt market shows that the likelihood of a default must not be assessed only using simple summary aggregate measures of public do-

\footnotetext{
* We would like to thank the following undergraduate research assistants who have worked on this project: Pedro César, Roberto Cohen, Tatiana Didier, Marina Fontoura, João Gomes, Rafael Marchesini and Débora Masullo. The Ph.D. student Gino Olivares helped us in the early phase of the project, and the M.Sc. student Aureo de Paula played a fundamental role throughout the whole project. Of course, all errors are our own. We also thank the comments from Michael Dooley, Affonso Pastore, and other participants of the 1998 Inter-American Conference in Economics, organized by the NBER and PUC-Rio.

* Departamento de Economia da Pontifícia Universidade Católica, Rio de Janeiro/RJ, Brasil. E-mail: afonso.bevilaqua@gmail.com.

*** Departamento de Economia da Pontifícia Universidade Católica, Rio de Janeiro/RJ, Brasil. E-mail: mgarcia@econ.puc-rio.br; Orcid: 0000-0003-1075-8213.
} 
mestic debt size and maturity, but must also consider other structural aspects. Our analysis emphasizes the two main pillars of the Brazilian public domestic debt market: home-bias and the role of the banking sector in intermediating the debt. Evidence from yields of a "perfectly" indexed bond shows that the rollover premium was very small when the devaluation occurred, and is still fairly small by October, 1999, indicating that the rollover of the public domestic debt is not, so far, a serious problem. Positive prospects for the public domestic debt market will depend, however, on the Brazilian government maintaining the current fiscal austerity program.

KEYWORDS: Banks, Public Debt, Currency Crises, Brazilian Economy

JEL Classification: F32; F34; G21.

\section{INTRODUCTION}

The Brazilian economy became the object of attention of the world financial community after mid-1998. High external current account and public sector deficits (projected at that time, respectively, at about 4.5 percent and 7.5 percent of GDP for $1998,{ }^{1}$ with dim prospects afterwards) were interpreted as indicative that Brazil was likely to be the next emerging market economy crashing as a result of a currency crisis, a forecast which proved to be accurate shortly after, when the country devalued on January 13,1999. On top of the twin deficits, a source of widespread concern was the country's sizeable and rapidly growing stock of domestic debt, most of it short-term. ${ }^{2}$

The concern with the domestic debt increased after the Russian default, in August, 1998. A couple of auctions in August-September with low coverage ratios were interpreted by international investors as a clear sign of an impending confidence crisis, in which the government would default on the contractual terms of its domestic debt by compulsorily lengthening its maturity. ${ }^{3}$ The fear was that, as it happened in Mexico before the devaluation of December 1994, investors would not rollover their maturing debt, and would flee the domestic currency, the real. According to this view, therefore, the currency crisis would be triggered by a domestic debt crisis.

The events have shown that the currency crisis occurred without the confidence crisis, and the likely banking crisis that would likely follow a domestic debt default. Based on other countries' recent currency crises, the consensus forecast immediately after the devaluation was a $4 \%$ fall in real GDP during 1999. As of early

\footnotetext{
${ }^{1}$ The current account deficit was $4.33 \%$ of GDP, and the nominal fiscal deficit was $7.58 \%$ of GDP (Banco Central do Brasil, September 1999).

${ }^{2}$ According to the IMF's description, the Brazilian “... economy remained vulnerable on account of a large and widening fiscal deficit, a large current account deficit, and a sizeable stock of short-term public debt, increasingly and largely indexed to overnight interest rates or the U.S. dollar" (IMF, World Economic Outlook, October 1998).

${ }^{3}$ Not all international investors, however, shared this interpretation. See Citicorp (1998).
} 
November, 1999, the same forecast is hovering around a slightly positive rate of growth $(0,5 \%)$. The surprising recovery of the Brazilian economy during 1999 was in great measure due both to the lack of a domestic debt roll over crisis, and the likely banking crisis that would likely follow a domestic debt default.

Notwithstanding this surprising performance, the fear of a confidence crisis continued to be a major source of macroeconomic instability in the Brazilian economy after the floating of the real. Previous debt restructuring programs such as the 1989 Bonex Plan in Argentina or the 1990 Collor Plan in Brazil often raise memories of severe financial disintermediation crises with profound effects on the real economy.

Interestingly enough, the perception of the need for the default, and therefore the assessment of the likelihood of a forced rescheduling of the domestic debt, has differed along the lines of national and foreign macroeconomic analysts, with few exceptions. ${ }^{4}$ Being the domestic banking sector a fundamental player in the intermediation process of the public debt, a default could prompt a financial crisis with serious consequences to the Brazilian economy. Given its sheer size, added by the financial and commercial links with neighbor economies, a large recession in the Brazilian economy would be a major factor in intensifying the current recession in Latin America, with possible important effects on other regions. Therefore, the perception of the Brazilian public debt default risk is a point of utmost importance, due to its potential to generate large macroeconomic instability in emerging markets.

In this paper we examine the recent evolution of the Brazilian public domestic debt, and interpret it according to the confidence crisis literature. We analyze the recent developments in the Brazilian domestic debt market, arguing that the likelihood of a domestic debt default must be assessed with more information than just simple summary aggregate measures of domestic debt size and maturity. These summary measures, however important they may be, must be complemented by other structural aspects of the debt market. Our analysis emphasizes the two pillars of the Brazilian domestic debt market: home-bias and the role of the banking sector in intermediating the public debt.

The paper has the following structure. Section 2 examines the maturity structure of domestic debt in Brazil in recent years, showing that the rollover of a large short-term domestic debt has not been unusual, and that the debt maturity has actually been increasing recently. Section 3 analyzes the home-bias in the Brazilian public debt market as a fundamental reason generating a large demand for domestic debt. Section 4 describes the intermediation process of the public debt. We show that debt management has been intertwined with liquidity control since the hyperinflation period. Furthermore, legal restrictions, and very high interest add to the home-bias in creating a captive demand for domestic public debt in Brazil. Section 5 presents empirical evidence from yields of Brazilian securities. Finally, Section 6 presents a few concluding remarks.

\footnotetext{
${ }^{4}$ For a forceful description of the rescheduling view see Deutsche Bank (1999). Citicorp (1998) presents an alternative account.
} 


\section{THE MATURITY STRUCTURE OF DOMESTIC DEBT}

During the period between the introduction of the new currency and the Asian crisis, the maturity of the Brazilian domestic public debt was gradually increased, based mostly on nominal debt. Chart 1 displays the evolution of the domestic public debt. In this chart, the different bond types are gathered by groups with common indexator (bonds indexed to the price level, to the exchange-rate, nominal bonds etc.). It also displays the average remaining life of the total debt stock, as well as the average remaining life and the average duration of the bonds auctioned to the public (as opposed to special placements in official or semiofficial financial institutions). Between July, 1994 and October, 1997 the average maturity of the stock of domestic debt increased from five to 15 months. ${ }^{5}$ During the same period the share of nominal debt in the total debt stock increased from $31,2 \%$ to $54,7 \%$. Notwithstanding the increase in debt size and maturity during the pre-crises period, the total market risk, as measured by standard V@R (Value-at-Risk) measures actually fell during that period, due to a remarkable fall in the volatility of bond yields. ${ }^{6}$

From the Asian crisis until the beginning of the Russian crisis, the public debt maturity substantially declined, as shown in Chart 1 . As the increasing riskness was translated in a much larger maturity premium, the government decided to place only shorter-term debt. With the fast recovery of the international capital markets in the first quarter of 1998 , longer maturity nominal debt started to be placed until May, 1998 as shown in Chart 2.7

With the Russian crisis, the maturity premium increased again. Chart 3 displays the behavior of the term structure of the interest rates in Brazil since the first quarter of 1998. Four series of interest rates are displayed: the basic inter-bank rate set by the Central Bank (TBC), the six-month interest rate of private securities (swap 6m), and auction yields of six-month treasury bills (LTN $-6 \mathrm{~m}$ ) and centralbank bills (BBC $-6 \mathrm{~m})$. Chart 3 shows that the private six-month fixed income instruments had yields (swap $6 \mathrm{~m}$ ) that served as lower bounds to the public bonds auctions yields (LTN6m and BBC6m) until mid-May, 1998. After that, the former significantly increased, while the Central Bank signaled with further reduction of its basic interest rate $(\mathrm{TBC})$.

For almost one year, no further placement of six-month maturity public debt was carried out, most likely because the Central Bank decided not to validate the higher interest rate required by the agents in the nominal public debt market. Faced

\footnotetext{
${ }^{5}$ Data recently released by the Central Bank (starting in August, 1996) show that the average remaining life of the bonds auctioned to the public (as opposed to special placements in official or semiofficial financial institutions) grew from 2.2 months in August, 1996 to 6.9 months in October, 1997.

${ }^{6}$ For a description of interest rate risk of nominal Brazilian bonds during the pre-crises period, see Barcinski (1999).

${ }^{7}$ Although longer maturity nominal debt was being placed, its quantity was not enough to counteract the fall in average remaining life, as shown in Chart 1.
} 
with the mistrust of international market players as of its ability to rollover the increasingly shorter-term debt, the government decided to signal that it could raise the debt maturity. That was accomplished by placing debt indexed to the short-term interest rate. Chart 4 shows that after the Central Bank and the Treasury decided to place only indexed debt in place of the maturing nominal debt, the average maturity significantly increased.

With the success of this maturity lengthening strategy, the government was able to show that the there was little credit risk perceived by the market. If the market were mostly pricing a risk associated with the debtor (credit risk) and not with the specific debt instrument (market risk), the substitution of indexed debt for nominal debt would not have resulted in much lower interest rates and higher maturities.

Despite the increase in maturity, the fear of a confidence crisis was ignited on August, 1998, when four auctions of indexed debt had low coverage ratios. Chart 5 shows the amounts offered and placed at public bonds auctions, as well as the coverage ratio, for the period July, 1998 to August, 1999. Given the previous experience with the Russian debt default, those events were interpreted by some international investors as a sign of an impending confidence crisis. However, the low coverage ratios were more a sign of the usual fight between the market and the Central Bank for higher yields than a sign of an imminent confidence crisis. The Central Bank at that time opted not to place the full quantity offered as a signal to the market that it would not accept to place indexed debt with a discount. As the next section will show, that decision is explained by the characteristics of the debt intermediation process in Brazil. When the auctions started again in late September, debt was placed with a premium. Only during the second semester of 1999, when domestic interest rates had already fallen substantially (see Chart 3A), a discount appeared in the auctions, as we will discuss in Section 5.

\section{HOME-BIAS}

The home-bias puzzle refers to very small share of foreign ownership of domestic securities, despite the large benefits of global diversification. Home-bias is a well known phenomenon in both equity and bond markets, although estimates for major industrial countries indicate that it is less pronounced in the bond market. ${ }^{8}$

It is not easy to document the share of foreign ownership in the domestic public bond market, since, besides the official instruments for international investors to invest in public bonds, the "foreign fixed income funds", there are other instruments (local funds) that foreigners may access. This makes impossible to distinguish between foreign and domestic investors in those funds. The reason why foreign investors may be investing in public bonds through channels other than the "foreign fixed income funds" is that, since 1993, capital controls on foreign inflows- aimed

\footnotetext{
8 "The International Monetary Fund estimates that the share of public debt held by nonresidents now exceeds 20 percent for the seven major industrial countries" (Obstfeld and Rogoff, 1996: 305).
} 
at deterring excessive investment in high-yield short-term public debt-gave an incentive to foreign investors to disguise their fixed income investments in some other (non taxed) form of foreign investment. ${ }^{9}$ In early 1998, however, foreign investors were allowed to transfer their funds to "foreign fixed income funds" without a penalty. That change turned the stock of those funds in a more credible estimate of the foreign investment in fixed income. On top of that, the so-called "63 caipiras" (capital inflows originally intended to agriculture finance, but actually invested in US dollar indexed public bonds) is another source of capital inflows to fixed income. In any case, market estimates of foreign ownership in the public bond market hovered around 1-3\% of total public debt (US\$ 2 billion in "foreign fixed income funds", and US\$ 5 billion in "63 caipiras”), as of November 1998. Even if that is an underestimate, it is very unlike that current foreign ownership of public debt at that time could have been above US\$ 15 billion. In summary, during the semester before the devaluation of January, 1999, Brazil lost around US\$ 45 billion of foreign reserves. After that period, the remaining stock of public debt in the hands of foreign investors became negligible. That, of course, was the proximate cause of the currency crisis, but it did not prompt a confidence crisis.

The sizeable home-bias in the Brazilian domestic public debt market probably goes a long way in explaining the less volatile demand for the domestic public debt, in stark contrast to what happened in Mexico in 1994, and in Russia in 1998. For example, before the devaluation of December 1994, according to the IMF, around $2 / 3$ of total Mexican domestic debt was held by foreign residents (IMF, 1995, p. 62). Even if those statistics reflect hidden leverage of Mexican financial institutions by foreign banks (see Garber, 1998), the important characteristic is that the funds are channeled from abroad. Calvo and Mendoza (1996) claim that the lack of a liquidity motive for foreign residents to hold domestic debt turn their debt holdings less stable than those of local investors. In summary, the home-bias makes the demand for domestic public debt less volatile than would be the case if foreign investors represented an important share of Brazilian domestic debt holders.

\section{DEBT INTERMEDIATION}

We turn now to the role of the banking sector as an intermediary of the public debt, pointing out several reasons why this intermediation may increase the demand for the public debt and create a captive market for it. As far as confidence crises are concerned, this turns out to be a positive effect. However, we will claim that there is no free-lunch, since the role of the banking sector as the intermediary of the public debt imposes constraints on monetary and fiscal policies.

\footnotetext{
${ }^{9}$ See Garcia and Valpassos (1999).
} 


\subsection{The public debt market in Brazil: Heritage from the megainflation years}

The public debt market in Brazil was reborn in the mid-1960s together with several financial reforms and the military government stabilization plan, the PAEG (see Bevilaqua, Carneiro, Garcia and Werneck, 1998). In the 1980s, the megainflation that evolved was not accompanied by a dollarization process, a unique Brazilian feature among several Latin American countries that went through a hyperinflation. A key factor to explain this Brazilian singularity was precisely the existence of a domestic currency substitute, i.e., bank deposits whose counterparts in the bank assets were public bonds. ${ }^{10}$ Despite many flaws in the indexation of the public debt, it has historically been a good hedge against inflation. A proof of that fact is that Brazil inherited a large public debt from the megainflation years, unlike other hyperinflationary episodes, in which the high inflation had destroyed the old debts.

The megainflationary years also generated a particular way of conducting monetary policy, in which debt management is very much intertwined with the provision of liquidity to the banking sector. As a matter of fact, both activities are actually carried out by the Central Bank, who besides advising the Treasury on the bonds' auctions, also acts as a last resort buyer in those auctions. ${ }^{11}$ In addition, the Brazilian Central Bank has traditionally placed its own debt.

Banks (and now, funds managed by banks) and the Central Bank act very much as partners in rolling-over the debt. Banks profit from high yield securities, and incur in very little market risk (the risk from bond price volatility). The genesis of this process occurred during the megainflation years. Then, inflation and, by consequence, the interest rate were very volatile. ${ }^{12}$ As inflation increased, the demand for M1 gradually fell to very small levels (less than 1.5\% of GDP in the months just before the Real plan). Nevertheless, as pointed out above, a true dollarization process never occurred in Brazil, as it happened in other Latin American countries. The reason why that was possible was the provision by the banking sector of a good domestic substitute for M1: deposits with high liquidity that paid an interest rate high enough to protect them from inflation erosion. Banks held public debt on the asset side and offered these interest-bearing deposits as liabilities. Since banks were highly leveraged, bond price volatility constituted a major risk factor for their balance sheets. It soon became clear that banks would only go along in providing these domestic currency substitutes if the market risk from interest rate volatility was mitigated. Several different types of indexation were developed, but, even indexed debt was not enough to immunize banks' portfolios from bond price volatility. In many occasions in the past, the Central Bank has bailed out the

\footnotetext{
${ }^{10}$ For a description of this domestic currency substitution process, see Carneiro and Garcia (1993) and Garcia (1996).

11 The Brazilian Constitution, written in 1988, has a dubious position regarding deficit financing. It forbids the Central Bank from financing the Treasury, but it allows the Central Bank to purchase Treasury bonds in order to conduct monetary policy.

${ }^{12}$ Data from a futures market for the price level that existed in Brazil in the 1980s show that forecast errors of one percentage point in one-month-ahead inflation forecasts were the rule (Garcia, 1992).
} 
market by buying public debt at price higher than the market price, in order to avoid to disturb this longlasting partnership with the banking sector.

The way monetary and debt policy operated in the megainflation years is basically the following. Public debt was placed mostly with financial institutions, which, in turn, offered these inflation-protected deposits to the non-financial private sector. Since inflation was very high (during many years, above $1,000 \%$ per year), nominal money demand was always increasing, while real money demand was naturally decreasing while inflation was growing. At the same time, because of their prohibitively high opportunity cost, banks tried to have zero non-remunerated excess reserves at the Central Bank. When banks needed more bank reserves to face the increased nominal money demand, the Central Bank conducted regular open market operations to provide the needed reserves. The most common situation in which monetary policy was conducted during the megainflation years was the socalled oversold market. The oversold situation occurs when banks need to transform public bonds in bank reserves in order to fulfill their reserve requirements at the Central Bank. Since megainflation caused both the high opportunity cost of excess bank reserves and the always increasing nominal demand for M1, it was only natural that an oversold situation in the market for bank reserves developed. ${ }^{13}$

Nevertheless, during many periods the market for bank reserves had been on an undersold situation. ${ }^{14}$ These were periods in which the Central Bank and the Treasury considered that the market was requiring too high a yield at the bonds auctions, and decided not to place enough bonds to balance the market. In such circumstances, the Central Bank would intervene daily in the market, conducting bond sales with overnight repurchase agreements (repos). For example, when there was high macroeconomic uncertainty, reflected on a very high term premium of public bonds, the Central Bank would opt not to place debt at the auctions, and to take daily loans from the (excessively) liquid banks. For example, on the eve of the Real plan, the undersold situation of the market reached over US\$ 12 billion, or $500 \%$ of the monetary base (Garcia, 1996).

In summary, during the megainflation, banks carried public debt to back their interest-bearing deposits. That was their main source of profitability, since the interest-bearing deposits were always coupled with regular demand deposit accounts, which paid no interest, being ipso facto extremely profitable. Despite the high inflation, the demand for non-remunerated bank deposits did not fall to zero, and constituted the main source of profits for the large Brazilian banks during the megainflation years (see Cysne, 1993, and Garcia, 1996). ${ }^{14}$ Frequent open market operations took

\footnotetext{
${ }^{13}$ With an oversold market, it becomes very easy for the Central Bank to place the interest rate where it deems fit. This is because the aggregate banking sector must have enough reserves to fulfill the reserve requirements, and, in an oversold market, the only source of banking reserves is the Central Bank. With an undersold market, the Central Bank control over the short-term interest rate is not the same, since banks may opt not to lend their excess reserves to Central Bank (in the form of repos). ${ }^{14}$ Figure 4 in Garcia (1996) shows the status of the bank reserves market from 1992 to 1994.

${ }^{14}$ Megainflation also kept credit products at very low levels. Only after the Real plan did credit products became more relevant in Banks' balance sheets.
} 
care of the provision of liquidity to the banking sector. Therefore, debt and monetary policy were much more interconnected than in developed countries.

That state of affairs did not change radically with inflation stabilization. Chart 6 shows the evolution of shares of total federal debt holdings by category. Unfortunately, these data are only available since October, 1994 and until September, 1998. Nevertheless, we can see that most of the debt has been historically placed with financial institutions, and, more recently, with funds managed by banks. Furthermore, experts believe that most of non-financial firms' share is actually intermediated by the banking sector, which would have hidden swap agreements with non-financial firms in order to provide liquidity to the public bonds at any time at a given agreed price. The usual agreement between a firm and a bank is for the former to buy a public bond, with the latter having the obligation of repurchasing it at a price set so that the firm receives the market interest rate for the investment period less a few percentage basis points corresponding to the bank's fee. Therefore, even after inflation stabilization, the role of the domestic banking sector in intermediating the public debt is overwhelming.

This partnership between banks and the Central Bank in the debt-bank reserves market has two sides on what concerns macroeconomic policy. On the one hand, it helps placing more public debt than otherwise would be likely. On the other hand, it very much rules out monetary policy options that would impose large losses to the banking sector. The burden of the high interest rate in the public debt market is mostly borne by the government, since the debt is either very short-term or fully indexed to the short-term interest rate (see Chart 1 ). Therefore, very small wealth effects to public bond holders resulted when the Central Bank raised the interest rate in September, 1998 to around $40 \%$ a month. This partnership makes it more difficult to lengthen the public debt maturity with non-indexed securities. However, once the adverse fiscal situation has been generating large increases to the public debt stock, and that the concern regarding an eventual confidence crisis is based on how flammable the demand for domestic public bonds is, this partnership turned out to be a good thing to avoid an imminent confidence crisis in the recent period. Nevertheless, the main source of vulnerability of the Brazilian economy-the high public sector deficit-is even more adversely affected by the high interest rates that prevailed during the crises period. Those high interest rates, given the debt indexation, do not harm banks' profitability.

\subsection{Portfolio allocation: Reserve and margin requirements, legal restrictions, and high domestic interest rate}

Given the fact that most of the public debt is intermediated by banks or funds linked to banks, establishing how volatile the demand for public debt is requires the investigation of the portfolio allocation rules of banks' treasurers and fund managers.

First of all, many bank liabilities, besides demand deposits, have reserve requirements which have to be fulfilled by public bonds deposited at the Central Bank. In the recent past, to burst a credit bubble at the beginning of the Real Plan, the Central Bank has even required reserve requirements on banks' loans. In March 1995, almost 
$42 \%$ of total public federal debt was held to fulfill reserve requirements! Chart 7 shows the amounts of reserve requirements held at the Central Bank.

On top of that, derivative transactions at the main Brazilian derivative exchange, BM\&F - The Brazilian Commodities and Futures Exchange, require large margin requirements, which are mostly fulfilled with public bonds. Chart 8 shows the series of the public bond stock demanded for margining purposes of derivative transactions added to the public bond stock held at the Central Bank to fulfill reserve requirements. Therefore, a non-negligible amount of total public debt is captively placed with the financial sector as requirements for their daily operation.

Regarding legal restrictions to international portfolio diversification, Brazil has a fairly liberal policy, although a few restrictions remain. To invest abroad, a domestic resident had basically two options by the end of 1998 . One was to transfer funds to a foreign account and to invest from there. This option enticed transaction costsmaking it not very attractive for small investments-, and regular domestic income $\operatorname{tax}$ (at the time, $27.5 \%$ ). The other option was a special class of domestic funds, the FIEX, which should carry a minimum of $60 \%$ of its portfolio in Brazilian external debt securities.

Local funds could not diversify abroad, except through investments in the already mentioned FIEXs. Therefore, most local funds, with the exception of the FIEXs, did not have external assets.

Banks were able to invest abroad through regular direct investment in their overseas subsidiaries. They were precluded, however, from holding large long foreign exchange positions in their portfolios; any excess above US\$ 15 million of long foreign exchange position per bank (maximum for large banks) had to be deposited at the Central Bank. Therefore, banks and funds were not fully free to quickly move back and forth their positions between foreign and domestic assets to profit from temporary arbitrage opportunities. In the event of a crisis, banks/funds would not be allowed to quickly shift their portfolios to foreign assets on behalf of their depositors/ investors. They would have to redeem their deposits/investments, and then convert those in foreign currency.

Another important aspect of the intermediation process by banks and funds which reduces the volatility of the demand for public debt is the widely accepted use of the Selic interbank interest rate on government bonds as a reference for financial indexation. The performance of the majority of the financial products offered by banks and funds is actually evaluated in terms of this reference rate. A practical consequence of this fact is that fund managers are encouraged to concentrate a large share of their portfolios on public debt in order to protect themselves from relative losses vis à vis their competitors.

\section{EMPIRICAL EVIDENCE FROM INDEXED BONDS' YIELDS}

This section presents empirical evidence from indexed bonds' yields in Brazil which shows that during the second semester of 1998 the perception of default risk on domestic bonds was not a key factor in driving the auctions with low coverage ratios. 
The megainflationary history of the Brazilian economy originated several different types of indexed bonds. The most peculiar one was the zero-duration bond. As shown in Charts 1 and 4, that bond-type became, after the second semester of 1998, the one with the highest share in total domestic bonded debt. Those bonds have the characteristic of completely eliminating the interest rate risk (in domestic currency). They pay the accrual of the daily Selic (interbank) rates from the auction to the redemption date. Therefore, if the interest rate is raised, the bond price in domestic currency does not fall. Since duration is the negative of the semi-elasticity of the bond price with respect to the interest rate, that explains its name. Abstracting from exchange-rate risk, this is as close to "perfect" indexation as one may get.

As discussed in Section 2, until the second semester of 1999, the zero-duration bonds were never placed with a discount. Placing those bonds with a discount would mean that the bond-holder would receive more, and that the issuer (the government) would pay more, than $100 \%$ of the accrual of the daily Selic (interbank) rates. Since the zero-duration bond has no market risk (i.e., interest rate risk), a discount would only appear if there was another source of risk. The main alternative sources of risk are either liquidity risk, or credit risk. These risk sources are associated with the rollover problem: in the presence of those risks, one would charge something for giving up liquidity through the purchase of a bond instead of rolling over the funds daily in the open market through the purchase of a bond coupled with a daily repurchase agreement offered by the Central Bank. In other terms, if a discount shows up, it is a sign that the repurchase agreement has a significant value, or that the option represented by the repurchase agreement-the one of redeeming the zero-duration bond every day instead of having to wait until the bond's maturity-has become more in-the-money. We, therefore, call rollover risk this combination of liquidity and credit risk against which the option represented by the repurchase agreement of a zeroduration bond serves as an insurance policy.

The fact that a discount had not been present in the auctions of the second semester of 1998 is indicative that the perception of rollover risk was not an important factor at the time. Looking at Chart 9, one can see that a discount has only developed after April 1999. This period coincides with a deterioration of the macroeconomic prospects of the Brazilian economy: the exchange rate depreciated some $14 \%$ and the yield curve became increasingly steeper (see Chart 3B). We now present a simple exercise in order to infer the rollover risk premium from the discount. As zero duration bonds are floating rate instruments yielding interest rates that are only known completely once the bond expires, the rollover risk premium (d) was computed according to the discount paid by investors at the auction:

$$
\begin{aligned}
& \begin{array}{l}
A P=100 \% \times \exp (-d . \# \text { years }) \\
\text { where } \quad A P=\text { average price at the auction; } \\
\quad d=\text { annual rollover risk premium; and } \\
\quad \# \text { years }=\text { number of years until maturity. }
\end{array} \\
& \begin{array}{l}
N P=100 \% \times \exp (-d) \\
\text { where } \quad N P=\text { normalized price at the auction. }
\end{array}
\end{aligned}
$$


Chart 10 presents the results. The bars are the maturities of the auctioned bonds, and the dark line is the discount, as presented in Chart 9. The computed risk premium is the light line. One can see that the while the discount had a large fall when one-year bonds started being placed in lieu of two-year bonds, the rollover risk premium-which was also rising before-stabilized. This behavior suggests that the market was indeed charging more for bearing more rollover risk. Chart 11 displays in a demand-curve-like fashion the normalized price (NP, see equation 2) of the zeroduration bonds against the cumulative quantities placed during the second half of 1999. Chart 11 suggests that the demand for domestic debt was becoming less elastic, given the prospects during the second semester of 1999, in stark contrast with what happened before the devaluation.

\section{CONCLUDING REMARKS}

This paper has examined the recent evolution of the domestic public debt in Brazil in light of the confidence crises literature. The Brazilian economy has been closely watched by the international financial community in recent months, and after the Russian crisis in May, 1998, there was an increasing concern that investors would not rollover their maturing debt, and would trigger a currency crisis fleeing the real.

As we argue in the paper, that concern was somewhat misplaced. The events in recent months have shown that the Brazilian currency crisis occurred without the confidence crisis, and the likely banking crisis that would likely follow a domestic debt default. The main source of vulnerability of the Brazilian economy was and continues to be the sustainability of its fiscal policy in the medium and long terms. The demand for domestic debt remains quite large on account of two basic factors. The first, is that the majority of the debt is held by domestic residents and not by foreign investors as in other emerging markets which had recently undergone external crisis. The second factor is the intermediation of the debt by the domestic banking system which confers it a large captive demand. The empirical evidence from "perfectly" indexed bond's yields confirms that rollover risk was virtually negligible before the devaluation and is still fairly small. The positive prospects of the Brazilian public domestic debt market will depend on the Brazilian government maintaining the current fiscal austerity program.

\section{REFERENCES}

BARCINSKI, A. M. A. (1999). Risco de Taxa de Juros e a Dívida Pública Federal no Brasil Pós-Real, Rio de Janeiro: BNDES, $22^{\circ}$ Prêmio BNDES de Economia.

BEVILAQUA, A. S., D. D. CARNEIRO, M. G. P. GARCIA, and R. F. L. WERNECK (1998). "The Structure of the Public Sector Debt in Brazil”, mimeo, Department of Economics, PUC-Rio, June.

CALVO, G. (1996). "Why is “the Market” so Unforgiving?”, mimeo, University of Maryland, September. 
CALVO, G. and E. MENDOZA (1996). "Mexico's Balance-of-Payments Crisis: A Chronicle of a Death Foretold", Journal of International Economics, v. 41 (3-4), November.

CALVO, G. (1998). "Varieties of Capital-Market Crises", in G. Calvo and M. King (eds.), The Debt Burden and its Consequences for Monetary Policy, London: Macmillan Press Ltd., IEA Conference, v. 118.

CARNEIRO, D. D. and M. G. P. GARCIA (1994). "Flujos de Capital y Control Monetario Bajo Sustitución Doméstica de Dinero: La Reciente Experiencia Brasileña”, in Roberto Steiner (ed.), Afluencia de Capitales y Estabilización en América Latina, Bogotá: Colombia, Fedesarollo.

CITICORP (1998). “Brazil Monitor”, Global Research — Emerging Markets, September.

CYSNE, R. P. (1993). “Imposto inflacionário e transferências inflacionárias no Brasil”, Working Paper, FGV, Rio de Janeiro.

DEUTSCHE BANK (1999). “Global Emerging Markets”, v. 2 (1), March.

GARBER, P. (1998). "Derivatives in International Capital Flow”, NBER Working Paper Series, Working Paper 6623, June.

GARCIA, M. G. P. (1992). "Política monetária e formação das expectativas de inflação: Quem acertou mais, o governo ou o mercado futuro?”, Pesquisa e Planejamento Econômico v. 22 (3), dezembro. GARCIA, M. G. P. (1996). “Avoiding Some Costs of Inflation and Crawling Toward Hyperinflation: The Case of the Brazilian Comestic Currency Substitute”, Journal of Development Economics, October.

GARCIA, M.G.P. and M. V. VALPASSOS (1999). “Capital Flows, Capital Controls and Currency Crisis”, in B. Larrain, Felipe (ed.), Capital Flows, Capital Controls and Currency Crises: Latin America in the 1990s, University of Michigan Press.

INTERNATIONAL MONETARY FUND (1995). International Capital Markets: Developments, Prospects and Policy Issues, August.

INTERNATIONAL MONETARY FUND (1998). World Economic Outlook, October.

KRUGMAN, P. (1979). "A Model of Balance of Payments Crises", Journal of Money, Credit and Banking.

OBSTFELD, M. and K. ROGOFF (1996). Foundations of International Macroeconomics, Cambridge, Mass.: The MIT Press.

Chart 1

Federal Bonds : Composition and Average Remaining Life

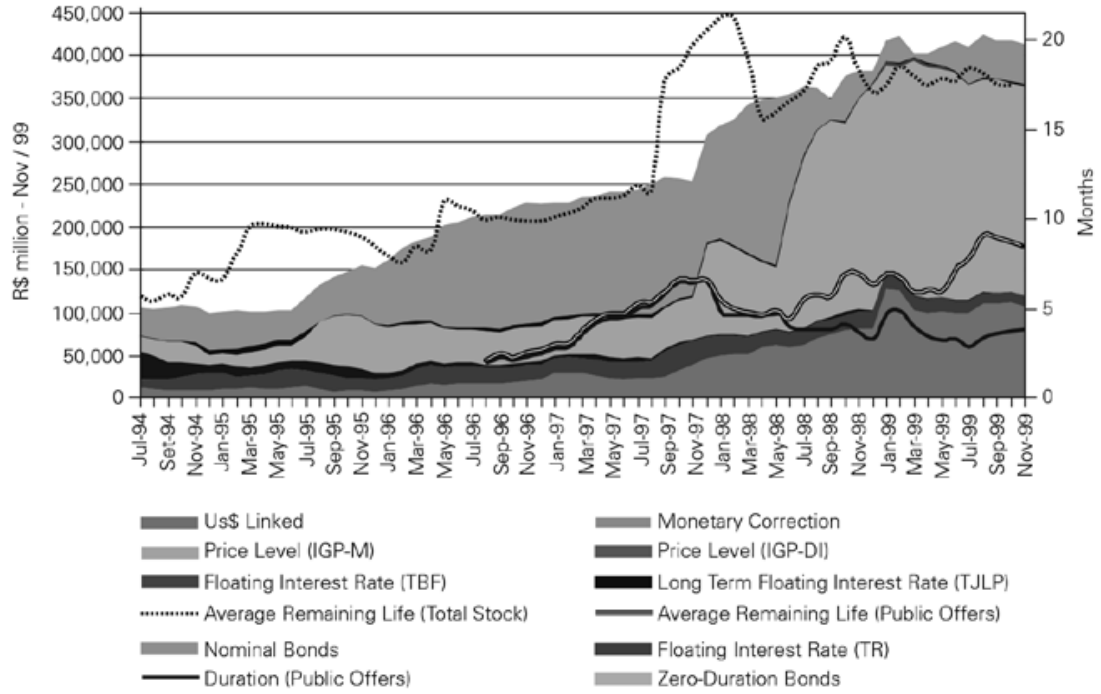


Chart 2 - A

Federal Public Bonds' Auctions - 1998

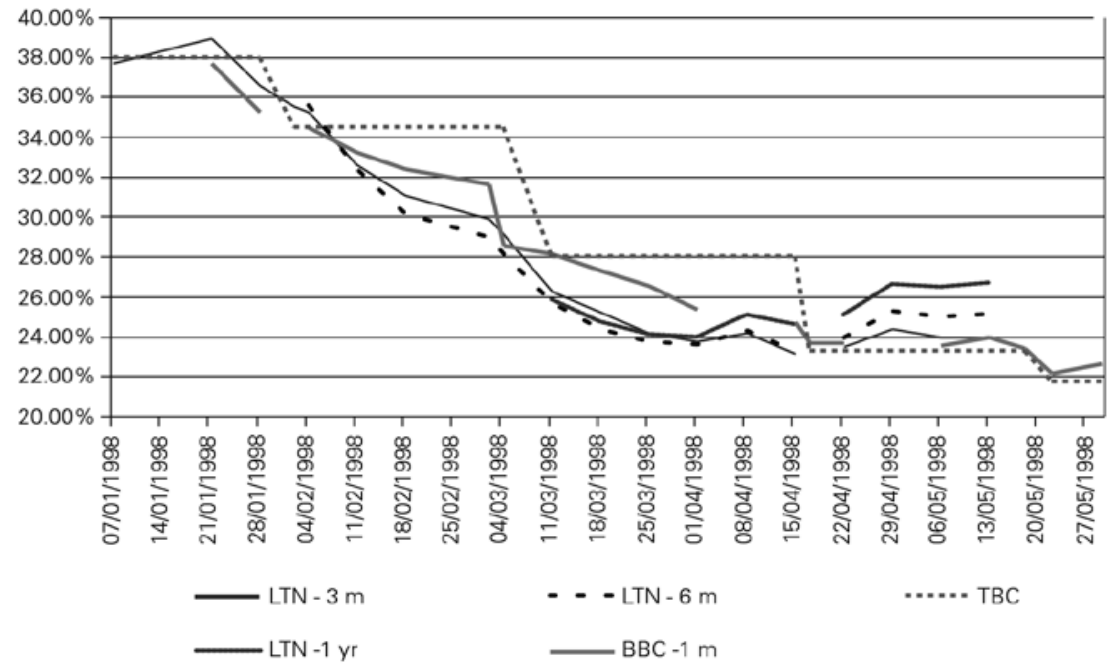

Chart 2 - B

Federal Public Bonds' Auctions - 1999

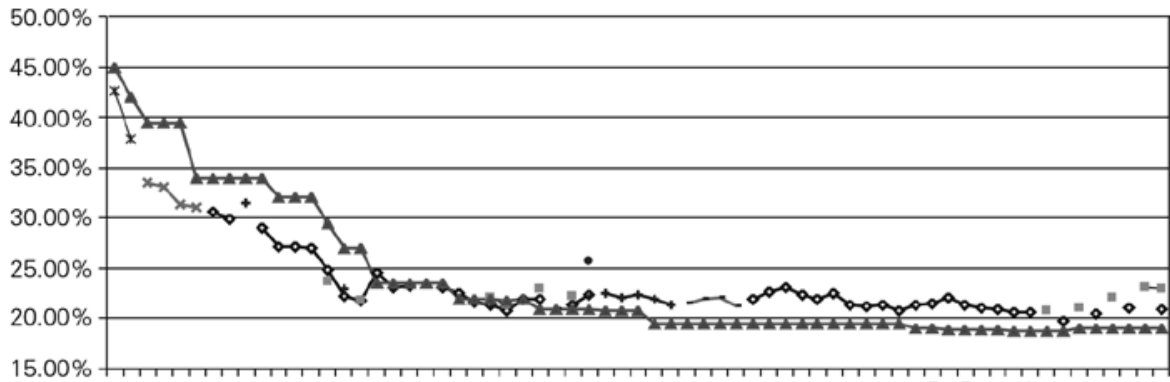

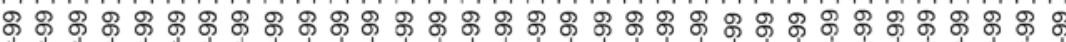

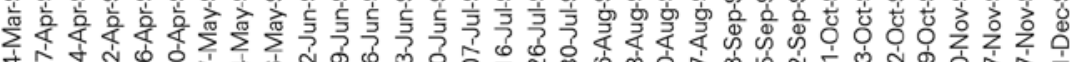
సิ่
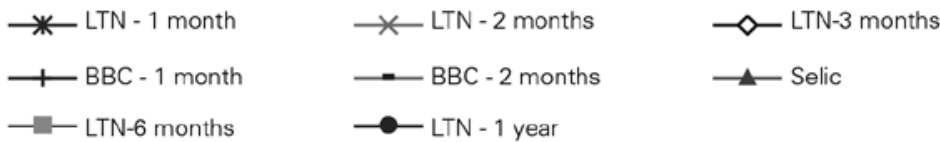
Chart 3 - A

Public Bonds' Auction Yields and Private Fixed-Income Securities Returns

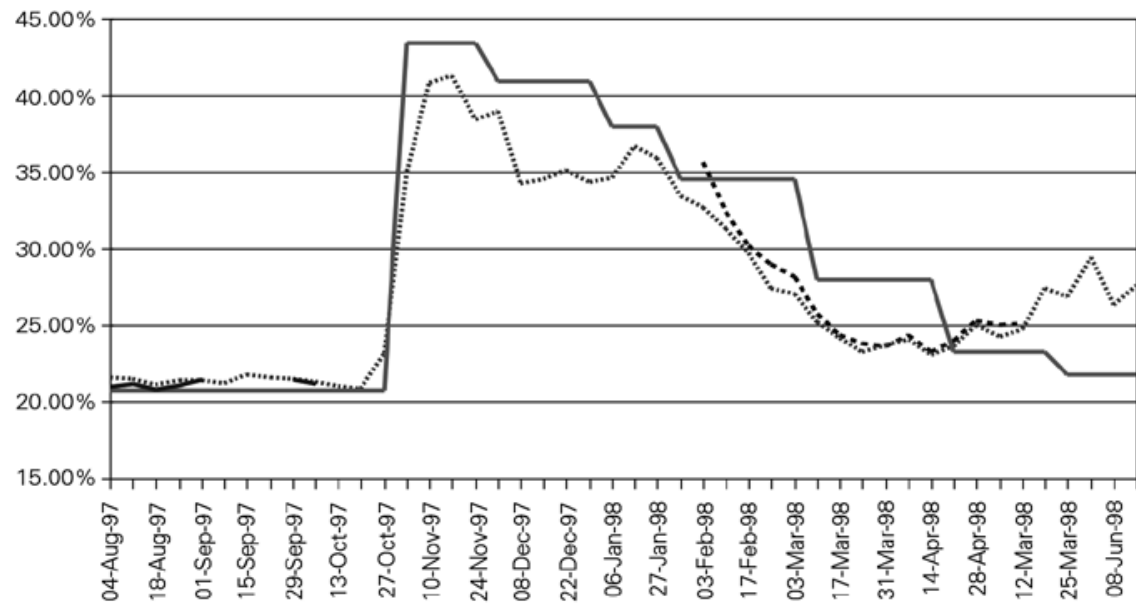

LTN-6 m …........ Swap $6 \mathrm{~m} \quad$ tbc $\longrightarrow$ BBC $-6 \mathrm{~m}$

Chart 3 - B

Public Bonds' Auction Yields and Private Fixed-Income Securities Returns

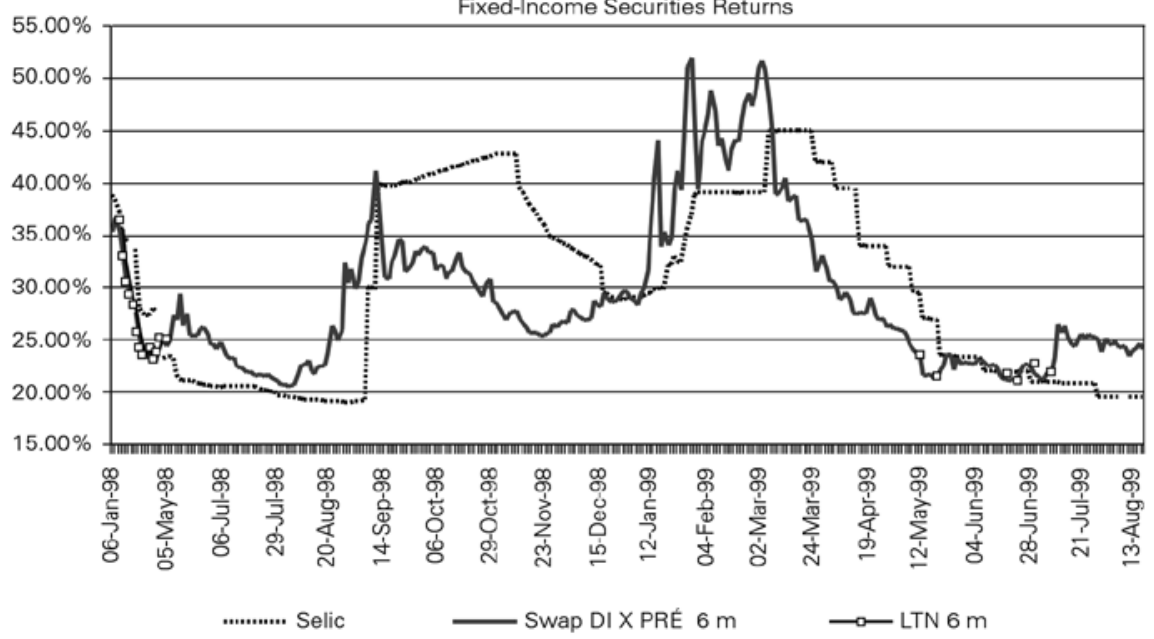


Chart 4

Public Bonds' Auctions, Volumes and Maturity

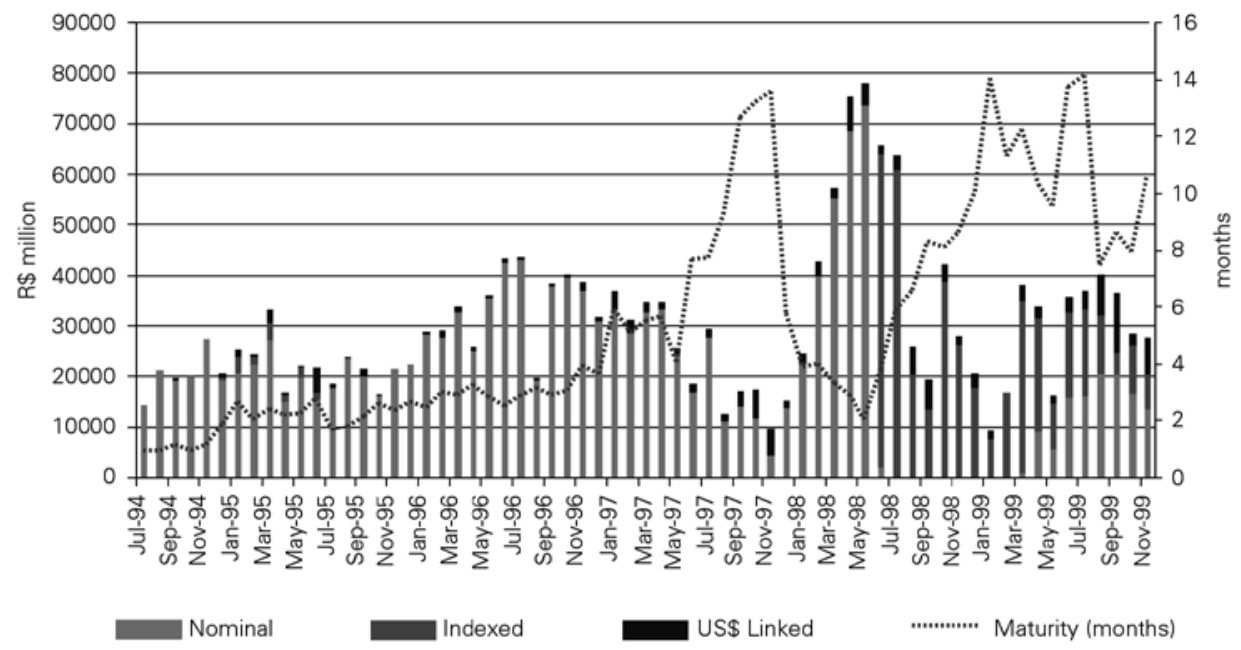

Chart 5

Indexed Debt Auction

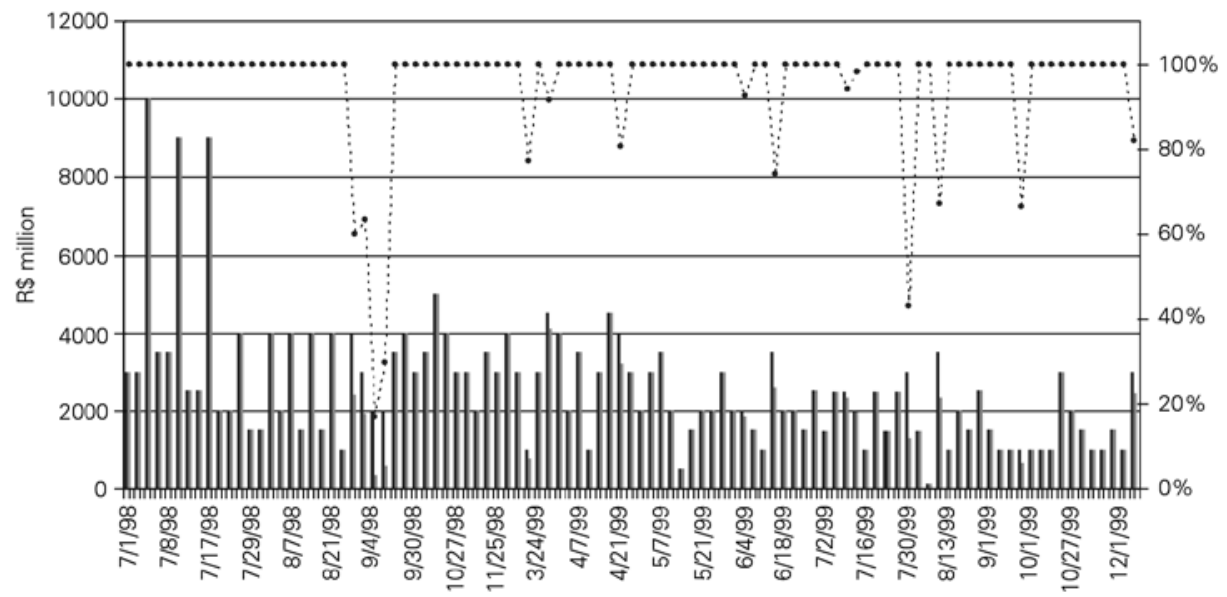


Chart 6

Federal Securities - by holders

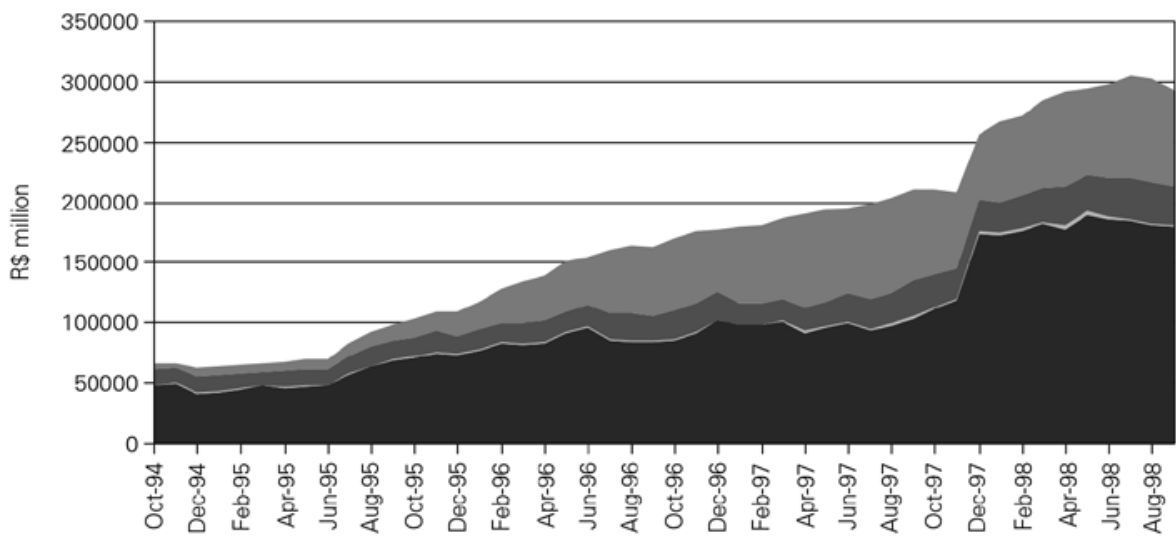

non-Financial Private Sector: Funds

- Non-Financial Private Sector: Non-Financial Firms

Non-Financial Private Sector: Households

- Financial Institutions

Chart 7

Total Reserve Requirements at the Central Bank

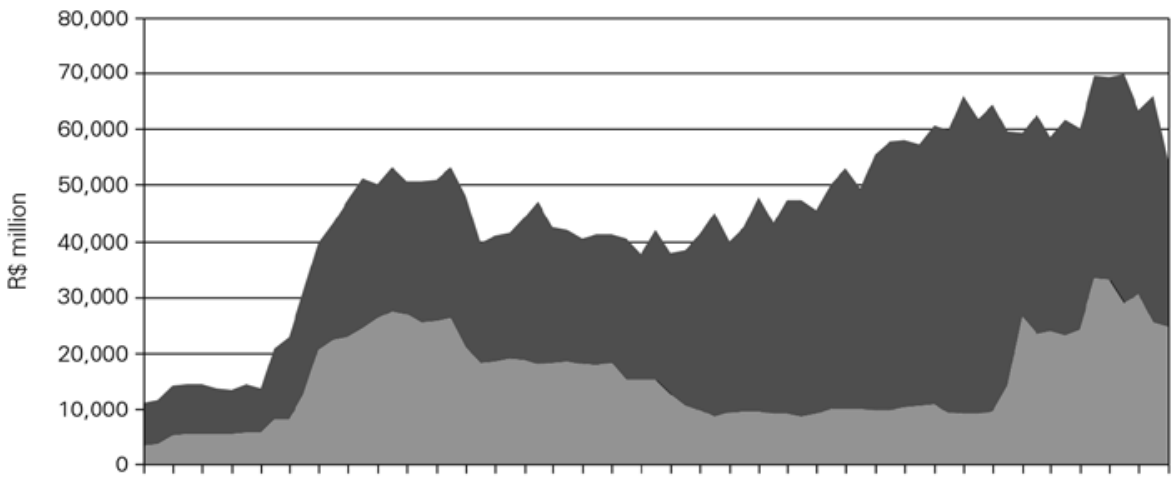

ஜ ळ

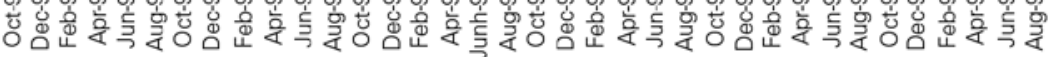

Bonds Others 
Chart 8

Public Bonds' Holdings: Reserve Requirements at the

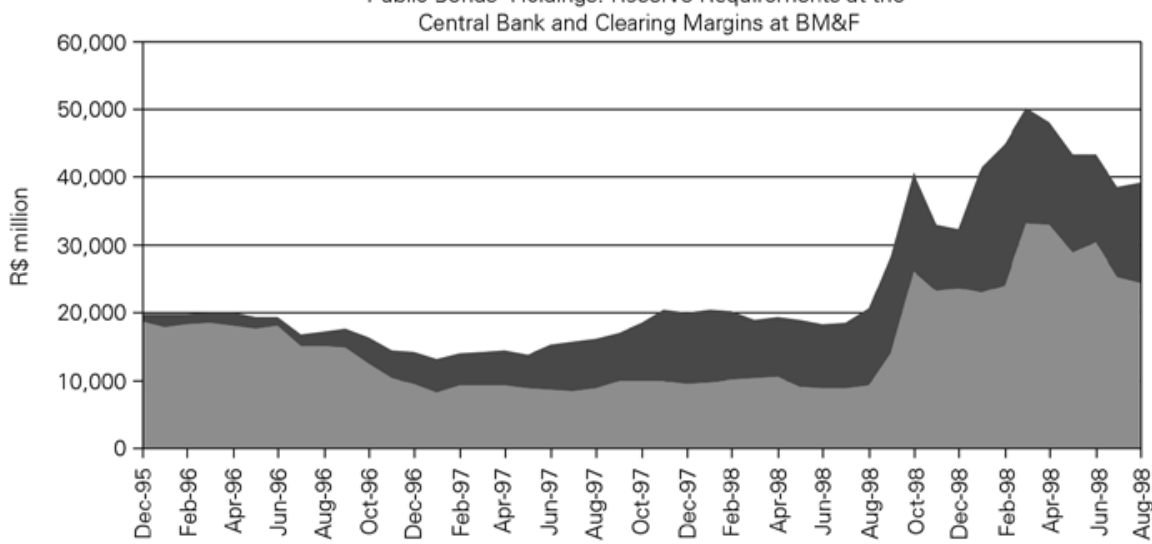

Central Bank BM\&F

Chart 9

Discount and Public Debt Placements

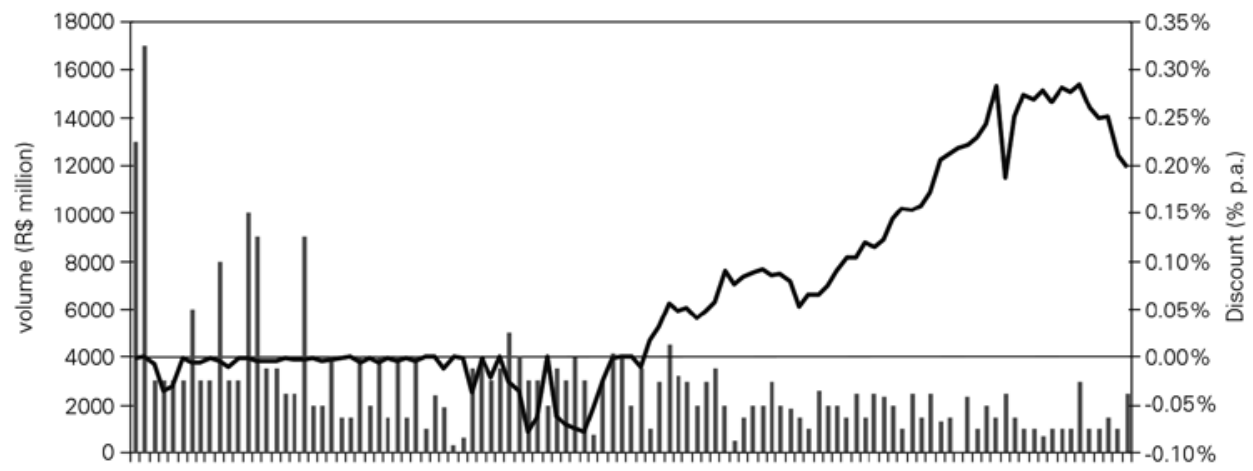

ஊ

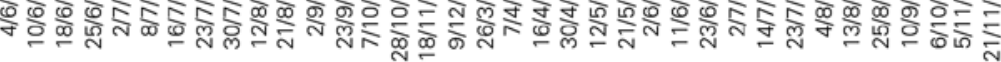

- Public Debt Placements _Discount 
Chart 10

LFT - Maturity and Risk Premium

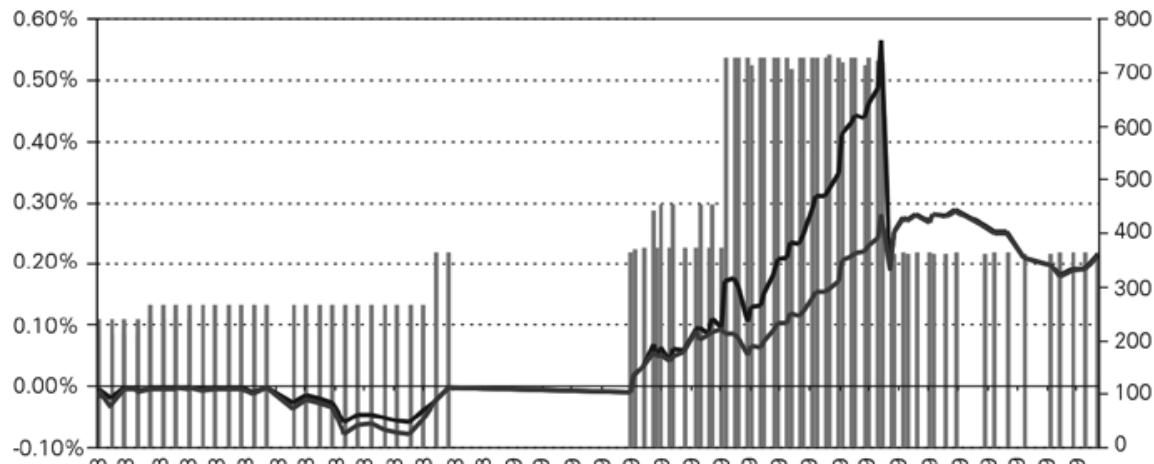

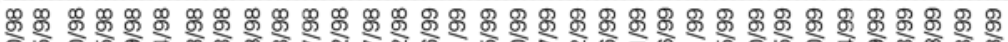

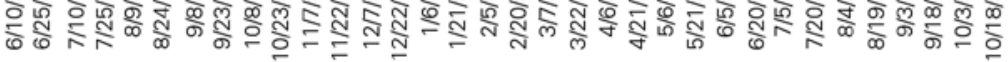

Maturity —Discount - Risk Premium

Normalized Price and Accumulated Quantities

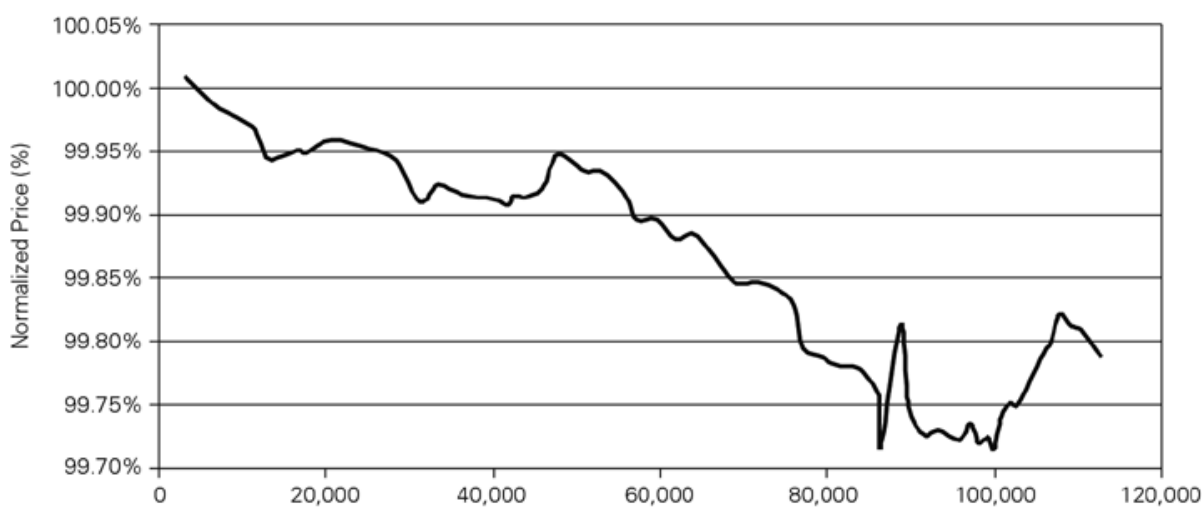

Cumulative Placements (R\$ million)

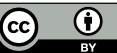

